\title{
A Study on the Relevance between Psychological Capital and Employment Ability of Normal University Girls
}

\author{
Keli Liao', Yanjin Liu \\ ${ }^{1}$ School of Psychology, Chengdu Normal University, Chengdu, China \\ ${ }^{2}$ School of Education, Chengdu Normal University, Chengdu, China \\ Email: keli85577273@126.com
}

How to cite this paper: Liao, K.L. and Liu, Y.J. (2019) A Study on the Relevance between Psychological Capital and Employment Ability of Normal University Girls. Open Journal of Social Sciences, 7, 69-75. https://doi.org/10.4236/jss.2019.77007

Received: June 13, 2019

Accepted: July 16, 2019

Published: July 19, 2019

Copyright $\odot 2019$ by author(s) and Scientific Research Publishing Inc. This work is licensed under the Creative Commons Attribution International License (CC BY 4.0).

http://creativecommons.org/licenses/by/4.0/

\section{c) (i) Open Access}

\begin{abstract}
Despite the increasing status of women in modern society and the increasing presence of women in the workplace, due to gender discrimination for a long time, employers have a clear "gender orientation" in the recruitment process, preferring to recruit male workers; women still struggle in employment, significantly lower than men in employment rate, although the proportion of men and women is similar in our country. Women account for the vast majority of normal school students, and the employment pressure is particularly prominent. In order to improve the employment rate of normal university girls, it is essential to enhance the employment ability of normal university girls. There are many factors affecting the employment ability of normal university girls. This paper studies the relationship between the psychological capital and the employment ability of normal university girls, in order to explore the important ways to improve the employment ability of normal university girls.
\end{abstract}

\section{Keywords}

Normal University Girls, Psychological Capital, Employment Ability

\section{Introduction}

The employment ability of normal school students is a comprehensive ability for normal school students to obtain job opportunities. It is mainly embodied in five aspects: practical ability, adaptability, interpersonal communication ability, employment confidence, self-development [1]. According to the literature, we can see that the previous scholars' research on university students' employment abil- 
ity mostly focused on the influencing factors of university students' employment ability, the measurement and evaluation index of university students' employment ability, and the measures to improve college students' employment ability.

The concept of "psychological capital" first appeared in the literature of economics, investment and sociology. In 1997, economists Goldsmith, Veum and Darity pointed out that psychological capital is a number of personality traits that can affect individual productivity [2]. In 2007, Luthans, Youssef and Avolio defined psychological capital as a positive mental state in the process of growth and development, which mainly includes self-efficacy, hope, optimism and resilience. That is to say: when a person is faced with challenges, he has full confidence to succeed; he has positive and optimistic attribution to the success to be achieved; he can persevere in achieving the goals and adjust the measures to achieve the realistic goals in a timely manner; he can persevere even when there are many difficulties [3].

Psychological capital affects all aspects of normal university girls' study and life. Whether psychological capital can improve their employment ability and thus improve their future employment rate is worth studying.

\section{Research Methods}

\subsection{Research Objects}

In this study, a stratified random sampling method was used to select female students from freshmen to juniors of a normal university from different majors and levels as subjects. 274 questionnaires were sent out and 274 were recovered, with a recovery rate of $100 \%$. After eliminating the incomplete questionnaires, 241 valid questionnaires remained, with an effective rate of $88 \%$ (Table 1 ).

\subsection{Research Tools}

\subsubsection{Psychological Capital Scale}

Psychological Capital Scale compiled by Luthans, Youssef and Avolio (2007) (translated by Li Chaoping in 2008) is applied, with 24 questions and four dimensions: self-efficacy, resilience, hope and optimism. The reliability and validity of the questionnaire are good. The internal Cronbach's Alpha coefficients of each dimension are $0.814,0.738,0.744$ and 0.797 respectively, and the internal consistency alpha coefficients of the whole scale are 0.822 .

\subsubsection{Employability Scale}

Lv Zhaohua's Self-Rating Scale for Employment Ability of College Students is selected, which contains five dimensions: self-development ability, employment self-confidence, interpersonal communication ability, practical ability and adaptability, 7 points each with seven rating scales-the higher the score, the stronger the employability. The Cronbach's Alpha coefficients of each dimension were $0.962,0.954,0.962,0.962$ and 0.957 , respectively. The Cronbach's Alpha coefficients of the whole questionnaire were 0.968 . 
Table 1. Basic situation of subjects.

\begin{tabular}{cccc}
\hline Project & Classify & Number of people & Percentage \\
\hline Grade & Freshmen & 82 & $34 \%$ \\
& Sophomores & 62 & $26 \%$ \\
& Juniors & 97 & $40 \%$ \\
Major & Primary Education & 132 & $55 \%$ \\
& Biological Sciences & 62 & $26 \%$ \\
& Arts Education & 21 & $8 \%$ \\
& Music Education & 26 & $11 \%$ \\
Academic level & Undergraduate & 159 & $66 \%$ \\
& Junior college & 82 & $34 \%$ \\
\hline
\end{tabular}

\subsection{Data Processing}

Microsoft Excel 2003 and SPSS 18.0 statistical software were used to process and analyze the data of questionnaire.

\section{Results and Analysis}

\subsection{Basic Situation Analysis of Psychological Capital of Normal Girls}

Through the statistical treatment of the psychological capital of normal university girls (Table 2), we can see that the average score of each dimension of the psychological capital of normal university girls is between 4.01 and 4.33 , and the total score of the psychological capital is 99.8 , which is in the middle level, meaning they can cope with general pressure and challenges. Self-efficacy score was 4.33 , the highest, and resilience score was 4.018 , the lowest. This may be because most of the girls in normal schools are from one-child families. They are the spoiled generation. They have not experienced setbacks and failures, and have no chance to hone their will.

One-way analysis of variance was conducted with grade as independent variable and psychological capital and scores of various dimensions of it as dependent variables. The results showed that there was no significant difference between grades in psychological capital and its dimensions. On the average, freshman's psychological capital score is 4.1997 , the highest; sophomore's is 4.0995 , the lowest. From the average of each dimension, freshman girls' self-efficacy score is 4.3943, resilience 4.0447 and optimism 4.3252, which are the highest in all grades, junior girls' hope score is the highest, 4.0790, and sophomores' self-efficacy, hope and optimism score is the lowest, 4.2581, 3.9543 and 4.1532, respectively. The reason may be that freshmen have successfully entered the university campus after a fierce college entrance examination. They are full of confidence in themselves and believe that they have perseverance and remain optimistic about the future. After a year's study, the sophomore girls have little knowledge of their majors and are confused about their future. After more than 
Table 2. Basic situation of psychological capital of normal girls.

\begin{tabular}{cccccc}
\hline & $\mathrm{N}$ & $\min$ & $\max$ & average & Standard deviation \\
\hline self-efficacy & 241 & 2.83 & 5.83 & 4.3278 & 0.57873 \\
hope & 241 & 1.50 & 5.67 & 4.0318 & 0.67110 \\
resilience & 241 & 1.67 & 6.00 & 4.0180 & 0.66885 \\
optimism & 241 & 2.00 & 6.00 & 4.2538 & 0.72250 \\
psychological capital self-evaluation & 241 & 48.00 & 138.00 & 99.7884 & 12.82871 \\
\hline
\end{tabular}

two years of intense professional studies, junior girls have a relatively deep understanding of the majors, and their own plans are initially shaped, full of hope for the future.

Using major as independent variable, psychological capital and scores of various dimensions of it as dependent variables for one-way analysis of variance, the results show that there is no significant difference in the dimensions of psychological capital between grades. From the average of each dimension, the scores of girls majoring in music and art are higher than those of other majors. The reason may be that these two majors belong to the art category. As long as students' employment requirements are not high, there will be a wide range of choices, in case that they cannot find a suitable job, they can start their own businesses. Therefore, they are confident of themselves, optimistic about the future and full of hope.

Using academic qualifications as independent variables and psychological capital and scores of various dimensions of it as dependent variables, for one-way analysis of variance, the results show that there is no significant difference in the dimensions of psychological capital between undergraduate girls and junior college girls. From the average of each dimension, the self-efficacy score of junior college girls was 4.3943, hope 4.0346, resilience 4.0447 and optimism 4.3252 , which were higher than that of undergraduate girls. The reason may be that the orientation of junior college girls is lower than that of undergraduate girls, and their requirements are lower, and their goals are easy to achieve.

\subsection{Basic Situation Analysis of Employment Ability of Normal Girls}

From the descriptive statistics of the employment ability of normal university girls, it can be seen that the average score of the employment ability of normal university girls is 394 , which is at a medium level. The average scores of each dimension of employability ranged from 4.4 to 4.8 , with the highest score of interpersonal communication ability being 4.8018 and the lowest score of practical ability being 4.4250 . This is related to the fact that children nowadays have a wide range of knowledge, interests and hobbies, are not afraid of strangers, and find it easy to communicate with others; as well as that they have a high vision, but low practical ability and everything is arranged by their parents.

Using grade as independent variable and employment ability and dimension 
score as dependent variables, the results show that there is no significant difference between grades. From the average, whether it is the overall employability score or the score of each dimension, the junior girls scored the highest: The overall score of employment ability was 4.4798 , self-development ability was 4.8256, interpersonal communication ability was 4.8557, employment confidence was 4.8356 , practical ability was 4.4467 , and adaptability was 4.7629 . The reason may be that after three years of theoretical study, professional probation and training of various associations in the university, their learning ability, professional knowledge, various skills and interpersonal communication have been greatly improved, and they are full of confidence in employment. First year students feel superior in all aspects to their success in entering the university campus through the college entrance examination. After more than a year of professional study, sophomores have lost their sense of superiority, are confused about their major, have not yet formed their skills in various fields, and do not know anything about what they can and will do in the future.

Using major as independent variable, employability and scores of its dimensions as dependent variables for one-way analysis of variance, the results show that there is no significant difference between different majors in employability and its dimensions. Judging from the average, both the overall score of employability and the scores of all dimensions are the highest for art majors, while the scores for other majors are very close. Maybe it's because art majors cover a wide range of fields, and a certain amount of art skills can be used in all walks of life.

Using academic qualifications as independent variables and employment ability and dimension scores as dependent variables for one-way variance analysis, the results show that there is no significant difference in the employment ability and its dimensions between undergraduates and junior college students. In terms of average, the scores of undergraduate girls are higher than those of junior college girls in terms of employment ability and various dimensions: the overall score of undergraduate students' employment ability is 4.4489, self-development ability is 4.7600 , interpersonal communication ability is 4.8200 , employment confidence is 4.7931 , practical ability is 4.4310 , and adaptability is 4.7433 . The overall score of professional employment ability was 4.4137 , self-development ability was 4.6829 , interpersonal communication ability was 4.7664 , employment self-confidence was 4.7503 , practical ability was 4.4134 , and adaptability was 4.7273 . The reason may be that undergraduate girls have developed better learning habits since they went to school and have a clearer life plan for themselves. In order to achieve their goals, they strive to exercise themselves in all aspects.

\subsection{Analysis of the Relationship between Psychological Capital and Employment Ability of Normal Girls}

1) The correlation analysis of psychological capital and employment ability of normal university girls. 
Psychological capital and its dimensions and employability and its dimensions are analyzed (Table 3 ) shows that psychological capital and its dimensions are positively correlated with employment ability and dimensions $(\mathrm{p}<0.01)$, which indicates that the higher the scores of psychological capital and its dimensions, the stronger their employment ability and ability of each dimension.

2) In order to further test the relationship between psychological capital and employability of normal university girls, the paper makes a regression analysis of employability with the dimensions of psychological capital as predictive variables (Table 4). All dimensions of psychological capital enter regression equation, which shows that psychological capital and its dimensions have predictive effect on employability, and psychological capital has $49.9 \%$ predictive effect on employability. In regression analysis, the non-standardized coefficients of each predictive variable were $0.634,0.692,0.635,0.454,0.915$, all positive, which shows that psychological capital has a positive impact on employability.

From the above research, the following conclusions can be drawn: there is a significant correlation between the psychological capital of normal university girls and their employment ability, and the psychological capital has a positive role in promoting the employment ability, that is, the better the psychological capital is, the stronger the employment ability is.

\section{Strategies to Improve the Psychological Capital of Normal University Girls to Enhance Their Employment Ability}

From the above statistical data analysis, it can be seen that all dimensions of psychological capital of normal university girls have a positive predictive effect

Table 3. Analysis of the correlation between psychological capital and employment ability of normal university girls.

\begin{tabular}{|c|c|c|c|c|c|c|}
\hline Factors & Self-development & $\begin{array}{c}\text { Interpersonal } \\
\text { communication }\end{array}$ & $\begin{array}{l}\text { Employment } \\
\text { Confidence }\end{array}$ & practical ability & Adaptability & $\begin{array}{l}\text { Self-assessment of } \\
\text { Employment Ability }\end{array}$ \\
\hline Self-efficacy & $0.473^{* *}$ & $0.488^{* *}$ & $0.511^{* *}$ & $0.517^{* *}$ & $0.474^{* *}$ & $0.530^{* *}$ \\
\hline Hope & $0.663^{* *}$ & $0.557^{* *}$ & $0.648^{* *}$ & $0.641^{* *}$ & $0.643^{* *}$ & $0.671^{* *}$ \\
\hline Resilience & $0.528^{* *}$ & $0.528^{* *}$ & $0.577^{* *}$ & $0.625^{* *}$ & $0.568^{* *}$ & $0.614^{* *}$ \\
\hline Optimism & $0.448^{* *}$ & $0.428^{* *}$ & $0.493^{* *}$ & $0.421^{* *}$ & $0.463^{* *}$ & $0.474^{* *}$ \\
\hline Self-evaluation of & $0.653^{* *}$ & $0.617^{* *}$ & $0.689^{* *}$ & $0.679^{* *}$ & $0.664^{* *}$ & $0.706^{* *}$ \\
\hline Psychological Capital & & & & & & \\
\hline
\end{tabular}

PS: ${ }^{*} \mathrm{p}<0.05 .{ }^{* *} \mathrm{p}<0.01$.

Table 4. Regression analysis of psychological capital and employment ability of normal university girls.

\begin{tabular}{|c|c|c|c|c|c|c|}
\hline $\begin{array}{l}\text { Predictive } \\
\text { variables }\end{array}$ & $\mathrm{R}$ & $\begin{array}{l}\text { Square } \\
\text { of } R\end{array}$ & $\begin{array}{c}\text { Square of } \\
\text { adjusted R }\end{array}$ & $\mathrm{F}$ & $\mathrm{B}$ & Sig \\
\hline Self-efficacy & 0.530 & 0.280 & 0.277 & 93.156 & 0.634 & 0.000 \\
\hline Hope & 0.671 & 0.450 & 0.448 & 195.841 & 0.692 & 0.000 \\
\hline Toughness & 0.614 & 0.377 & 0.374 & 144.333 & 0.635 & 0.000 \\
\hline Optimism & 0.474 & 0.225 & 0.221 & 69.257 & 0.454 & 0.000 \\
\hline Self-evaluation of & 0.706 & 0.499 & 0.496 & 237.649 & 0.915 & 0.000 \\
\hline Psychological Capital & & & & & & \\
\hline
\end{tabular}


on employment ability. Therefore, in order to enhance their employment ability, they should enhance their psychological capital: On the one hand, normal universities should carry out various forms of education and teaching activities according to the characteristics of female students, such as: mandarin competition, classroom teaching competition, dance competition and so on, so that every female student can participate in the activities as far as possible, and be able to achieve success, experience the joy of success, and enhance self-efficacy; on the other hand, today's children, all of whom are the only child, have relatively superior living conditions, and all their affairs are basically arranged by their parents from childhood to adulthood. Therefore, normal colleges and universities should: encourage students to actively participate in innovation and entrepreneurship activities of university students, meet challenges in the activities, and fight against pressure in the competition; carry out social practice activities with certain difficulties. For example, teaching in remote rural schools, honing their will and exercising their resilience in practice; training their female students to make correct attributions and not always look for various external excuses in the face of difficulties and setbacks, they should analyze more from their own internal factors, whether they lack meticulous planning for each project or their own knowledge, skills or efforts, etc. [4], so as to constantly improve themselves; finally, train normal university girls to have a positive and optimistic thinking in everything.

In a word, normal universities should fully tap the psychological potential of female students, consciously develop their psychological capital from self-efficacy, perseverance and resilience to deal with setbacks and difficulties, rational management of their emotions, positive attribution model and hope, so as to enable normal university girls to have competitive advantages in future employment and improve their employment rate.

\section{Conflicts of Interest}

The authors declare no conflicts of interest regarding the publication of this paper.

\section{References}

[1] Lv, Z.H. (2012) The Correlation Research between Psychological Capital and Employment Ability of College Students. Guangxi Normal University, Nanning.

[2] Goldsmith, A.H., Darity, W. and Veum, J.R. (1998) Race, Cognitive Skills, Psychological Capital and Wages. Review of Black Political Economy, 26, 13-22. https://doi.org/10.1007/s12114-998-1001-0

[3] Luthans, F., Youssef, C. and Avolio, B.J. (2007) Psychological Capital: Developing the Human Competitive Edge. Oxford University Press, Oxford, 217-229.

[4] Wang, W. (2018) The Status of Psychological Capital of Adult College Students and Suggestions for Improvement. China Adult Education, 3, 56-69. 